\title{
FAME, PARODY, AND POLICING IN TRADEMARK LAW
}

\author{
Mark A. Lemley*
}

2019 MiCH. ST. L. REV. 1

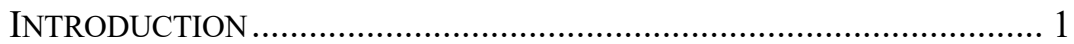

I. The TRAdemark Police STATE ...................................................... 2

II. POLICING PARODIES ........................................................... 10

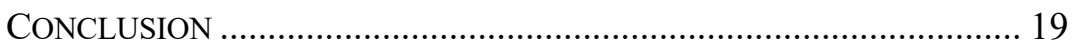

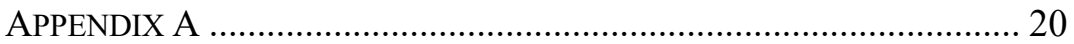

\section{INTRODUCTION}

Trademark owners regularly overreach. They often threaten or sue people they have no business suing, including satirists, parodists, non-commercial users, and gripe sites. When they do, they often justify their aggressive legal conduct by pointing to the need to protect their trademarks by policing infringement. Courts have in fact indicated at various points that policing is, if not strictly necessary, at least a way to strengthen a mark. But courts have never held that efforts to block speech-related uses are necessary or even helpful in obtaining a strong mark. Several scholars have accordingly argued that overzealous policing is unnecessary, has harmful effects, and ought to be punished. But trademark owners continue to do it, in part because it is largely (though not completely) costless, and because if there is even a chance a failure to police will cost owners their trademark, they won't want to take the chance. So, not only does trademark law currently fail to prevent overreaching, it affirmatively encourages it.

In this Article, I suggest a way that we can align trademark owner enforcement incentives with good public policy. The presence of unauthorized parodies, satires, and complaint sites related to a mark should be evidence of the fame of the mark and perhaps even a requirement for status as a famous mark. Taking this approach would

* William H. Neukom Professor, Stanford Law School; partner, Durie Tangri LLP. Thanks to Barton Beebe, Stacy Dogan, Eric Goldman, Leah Chan Grinvald, Rose Hagan, Mark McKenna, Lisa Larrimore Ouellette, Alexandra Roberts, Steve Ross, and Rebecca Tushnet for comments and helpful discussions and James Yoon and Andrew McCreary for excellent research assistance. (C) 2019 Mark A. Lemley. 
be consistent with what we know about how society interacts with trademarks. Famous marks become part of a social conversation in a way that ordinary marks don't. ${ }^{1}$ My approach has empirical support: The best-known brands draw more parodies and criticism sites than non-famous marks, and those parodies don't interfere with the fame of the mark. And my approach would give trademark owners an affirmative reason to leave critics, satirists, and parodists alone.

In Part I, I talk about the problem. In Part II, I talk about how we might solve it and consider some objections.

\section{THE TRADEMARK POLICE STATE}

Trademark owners regularly overreach. They make extremely broad claims for their marks, trying to control simple shapes, words, or even letters regardless of context or of whether trademark law gives any right over those things. Sometimes these claims are brought against competitors. ${ }^{2}$ Other times they are brought against companies in very different product fields who want to use a similar mark or $\log .^{3}$

More alarming, trademark owners regularly bring claims against social and political speech that uses their marks in ways they don't

1. See Jessica Kiser, Brandright, 70 ARK. L. ReV. 489, 493 (2017); Giulio Ernesto Yaquinto, Note, The Social Significance of Modern Trademarks: Authorizing the Appropriation of Marks as Source Identifiers for Expressive Works, 95 TEX. L. REV. 739, 740 (2017); Rochelle Cooper Dreyfuss, Expressive Genericity: Trademarks as Language in the Pepsi Generation, 65 Notre DAME L. ReV. 397, 397 (2014).

2. See, e.g., M.Z. Berger \& Co. v. Swatch AG, 787 F.3d 1368, 1370, 1371 (Fed. Cir. 2015) (holding that the registrant of "iWatch" lacked the requisite intent for validity in a case brought by competitor Swatch); Deere \& Co. v. M.T.D. Prods., Inc., 41 F.3d 39, 41 (2d Cir. 1994) (affirming the injunction of a mark's use by a competitor, even in the context of an attack ad).

3. See, e.g., Kellogg Co. v. Toucan Golf, Inc., 337 F.3d 616, 624-25 (6th Cir. 2003) (denying claims by a cereal maker with "Toucan Sam" word mark and logos against a golfing company with "Toucan Gold" word mark and logos); Kim Bhasin, Adidas Trademark War Means Three Stripes and You're in Court, BLOOMBERG (Mar. 15, 2017 4:00 AM), https://www.bloomberg.com/news/articles/ 2017-03-15/adidas-trademark-war-means-three-stripes-and-you-re-out\#footnote1489527826255 [https://perma.cc/F5FT-XSD9] (describing Adidas contesting Tesla's Model 3 car logo registration for supposed similarity to its three stripes, leading Tesla to withdraw its application and change its logo without litigation). Parodies of course often involve unrelated products if they involve products at all. See, e.g., Ringling Bros.-Barnum \& Bailey Combined Shows, Inc. v. Utah Div. of Travel Dev., 955 F. Supp. 605, 608-09 (E.D. Va. 1997) (alleging that the mark "Greatest Snow on Earth" for state license plate and tourism marketing purposes diluted plaintiff"s "Greatest Show on Earth" mark for a circus). 
like. Trademark owners sue parodists. ${ }^{4}$ They sue satirists. ${ }^{5}$ They sue gripe sites. ${ }^{6}$ They sue competitors who make fun of them ${ }^{7}$ and other

4. See, e.g., E.S.S. Entm't 2000, Inc. v. Rock Star Videos, Inc., 547 F.3d 1095, 1097, 1101 (9th Cir. 2008) (holding the "Pig Pen" club depicted in the streets of a Grand Theft Audio video game was protected parody of the "Play Pen" club); Mattel, Inc. v. Walking Mountain Prods., 353 F.3d 792, 796 (9th Cir. 2003) (affirming summary judgment for defendant artist of "Barbie Enchiladas," "Fondue a la Barbie," and other artistic parodies); Mattel, Inc. v. MCA Records, Inc., 296 F.3d 894, 908 (9th Cir. 2002) (holding "[t]he parties are advised to chill" in the case of Barbie maker against the record company behind "The Barbie Girl" song); Hormel Foods Corp. v. Jim Henson Prods., Inc., 73 F.3d 497, 500 (2d Cir. 1996) (holding Muppet character "Spa'am" did not infringe SPAM trademark); Louis Vuitton Malletier, S.A. v. My Other Bag, Inc., 156 F. Supp. 3d 425, 430 (S.D.N.Y. 2016) (holding that a canvas tote that depicted a Louis Vuitton handbag with the text "My Other Bag" in a parody of "my other car" bumper stickers did not infringe Louis Vuitton's trademarks); see also Stacey L. Dogan \& Mark A. Lemley, Parody as Brand, 47 U.C. DAVIS L. ReV. 473, 474-77 (2013) (reviewing trademark cases involving parodies).

5. See, e.g., Dr. Seuss Enters., L.P. v. Penguin Books USA, Inc., 109 F.3d 1394, 1400-01, 1406 (9th Cir. 1997) (holding use of Dr. Seuss trademark was satiric not parodic and so unprotected); L.L. Bean, Inc. v. Drake Publishers, Inc., 811 F.2d 26, 27, 34 (1st Cir. 1987) (holding a pornographic magazine's two-page "L.L. Beam's Back-To-School-Sex-Catalog [sic]" feature was a protected parody of the L.L. Bean catalog); Bill Donahue, Brand Battles: HBO Aims to Depose 'Game of Thorns', LAw360 (Oct. 12, 2018), https://www.law360.com/articles/1091764 [https://perma.cc/KP7J-T3X8] (reporting a challenge by the owners of the Game of Thrones trademark against an effort by a botanical garden to brand its educational programs "Game of Thorns"); Bill Donahue, Brand Battles: NASA, Ivy League, 'Lord of the Rings', Law360 (Oct. 5, 2018), https://www.law360.com/articles/1089922 [https://perma.cc/NBD6-D3XY] (reporting a challenge by the owners of the Lord of the Rings trademark against a confectioner who wanted to use "Lord of Meringues" as a trademark); see also Dogan \& Lemley, supra note 4, at 498-500 (discussing cases and the elusive distinction between parody and satire); $c f$. Campbell v. Acuff-Rose Music, Inc., 510 U.S. 569, 580-81 (1994) (distinguishing parody in a copyright context, which pokes fun at the protected material, from satire, which uses the protected material to poke fun at something else, but noting that both can be protected).

6. See, e.g., Lamparello v. Falwell, 420 F.3d 309, 311, 321-22 (4th Cir. 2005) (holding no actionable infringement for use of Reverend Jerry Falwell's mark in www.fallwell.com, a noncommercial site critical of Falwell's views on gay people); Bosley Med. Inst. v. Kremer, 403 F.3d 672, 674 (9th Cir. 2005); TMI, Inc., v. Maxwell, 368 F.3d 433, 434, 440 (5th Cir. 2004) (holding no violation of the Lanham Act for www.trendmakerhome.com, a website critical of the company of that name); Taubman Co. v. Webfeats, 319 F.3d 770, 778 (6th Cir. 2003); Savannah Coll. of Art \& Design, Inc., v. Houeix, 369 F. Supp. 2d 929, 935, 957-58 (S.D. Ohio 2004) (holding graduate student's scad.info and other websites critical of SCAD not actionable under the Lanham Act because noncommercial uses of the mark are not actionable under the Lanham Act); Bally Total Fitness v. Faber, 29 F. Supp. 2d 1161, 1168 (C.D. Cal. 1998). 
companies who make cultural references to them. ${ }^{8}$ They sue movies and TV shows that depict their products in ways they find unflattering. ${ }^{9}$ They sue politicians who use their marks in campaign ads and speeches. ${ }^{10}$ They sue people who use their trademarks to talk about the plaintiff's own products. ${ }^{11}$ They sue people who make posters, T-shirts, and plush toys that evoke their marks, even when it is beyond doubt that it is not the trademark owners who are selling those products. ${ }^{12}$

7. See, e.g., Deere \& Co., 41 F.3d at 41 (affirming the injunction of a competitor's attack ad with an animation of a John Deere deer fleeing a small barking dog and its own Yard-Man lawn tractor).

8. See, e.g., Louis Vuitton Malletier, S.A. v. Hyundai Motor Am., No. 10 Civ. 1611(PKC), 2012 WL 1022247, at*1 (S.D.N.Y. Mar. 22, 2012) (finding that a one-second shot in a Hyundai Super Bowl commercial of a basketball covered in interlocking LV marks infringed on and diluted Louis Vuitton's trademark); Am. Dairy Queen Corp. v. New Line Prods., Inc., 35 F. Supp. 2d 727, 728-29 (D. Minn. 1998) (enjoining a film about rural beauty contest seeking to use "Dairy Queens" as title).

9. See Mark A. Lemley \& Mark McKenna, Irrelevant Confusion, 62 STAN. L. REV. 413, 420-21 \& nn.31-34 (2010) (describing instances where New York University, Stanford University, the University of Utah, and Major League Baseball objected to their depictions in television shows and movies); William McGeveran, Rethinking Trademark Fair Use, 94 IowA L. REV. 49 (2008).

10. See, e.g., MasterCard Int'l, Inc. v. Nader 2000 Primary Comm., Inc., No. 00 Civ.6068(GBD), 2004 WL 434404, at*1, *16 (S.D.N.Y. Mar. 8, 2004) (finding that a political ad using Mastercard's "Priceless" template to critique the presence of money in politics to be noncommercial and non-misleading). I represented Nader in this case. See also Hershey Co. v. Friends of Steve Hershey, 33 F. Supp. 3d 588, 595 (D. Md. 2014) (granting an injunction for candy bar maker against Senator Hershey's campaign for using Hershey Co.'s trade dress to leverage its goodwill and not "for parody, political commentary, or other communicative purposes"); Lucasfilm Ltd. v. High Frontier, 622 F. Supp. 931, 935-36 (D.D.C. 1985) (dismissing a filmmaker's complaint against political groups using "Star Wars" to describe President Reagan's Strategic Defense Initiative).

11. See, e.g., Toyota Motor Sales, U.S.A., Inc., v. Tabari, 610 F.3d 1171, 1182-83 (9th Cir. 2010) (vacating an injunction against a non-misleading use of Toyota marks by an independent auto broker); Playboy Enters., Inc. v. Welles, 279 F.3d 796, 799-800 (9th Cir. 2002) (holding a former Playboy Playmate's use of Playboy's marks to describe her career nominative); New Kids on the Block v. News Am. Publ'g, 971 F.2d 302, 308-09 (9th Cir. 1992) (holding the use of band's name in newspaper poll was nominative under a new test).

12. See Bd. of Supervisors for La. State Univ. Agric. \& Mech. Coll. v. Smack Apparel Co., 550 F.3d 465, 481-82 n.54 (5th Cir. 2008) (finding infringement even though parties earlier stipulated that no consumer was actually confused about the origin or licensure of knock-off university sports apparel); Louis Vuitton Malletier S.A. v. Haute Diggity Dog, L.L.C., 507 F.3d 252, 261, 263 (4th Cir. 2007) (holding that a plush "Chewy Vuitton" puppy toy was a non-infringing parody of Louis Vuitton, which succeeded by allowing consumers to "to perceive the target of the 
Sometimes - too often - the trademark owners win these suits. ${ }^{13}$ More often they lose. ${ }^{14}$ But even claims that are unlikely to win often have the desired effect of scaring off the users. Defending a trademark case is expensive, the outcome is uncertain, and the payoff is limitedyou get to keep doing what you were already doing. As a result, far too many people and companies with meritorious defenses simply drop their parody, satire, complaint, or commentary rather than face the prospect of litigation. ${ }^{15}$ The result is that even though trademark

parody, while simultaneously allowing them to recognize the changes to the mark that make the parody funny or biting"); N. Face Apparel Corp. v. Williams Pharmacy, Inc., No. 4:09CV2029RWS, 2010 WL 546928, at *1 (E.D. Mo. Feb. 9, 2010) (discussing a case The North Face brought against the maker of "The South Butt" apparel); Smith v. Wal-Mart Stores, Inc., 537 F. Supp. 2d 1302, 1340 (N.D. Ga. 2008) (holding "WALOCAUST," "WAL-QAEDA," and similar terms used on merchandise sold by a critic of Wal-Mart to be First Amendment-protected, non-infringing uses); Coca-Cola Co. v. Gemini Rising, Inc., 346 F. Supp. 1183, 1193 (E.D.N.Y. 1972) (enjoining the sale of "Enjoy Cocaine" poster stylized like "Enjoy Coca-Cola" poster); Cat Weaver, Blurring Luxury and Art: Nadia Plesner vs Louis Vuitton, HYPERALLERGIC (Mar. 25, 2011), https://hyperallergic.com/21392/nadia-plesner-vslouis-vuitton/ [https://perma.cc/J3QF-72CA] (discussing Louis Vuitton's suit against an artist who depicted a child in a painting holding a Louis Vuitton purse).

13. See, e.g., Elvis Presley Enters., Inc. v. Capece, 141 F.3d 188, 191 (5th Cir. 1998) (enjoining "Velvet Elvis" as restaurant name); Gucci Shops, Inc. v. R.H. Macy \& Co., 446 F. Supp. 838, 839, 841 (S.D.N.Y. 1977) (enjoining the sales of "Gucchi Goo" diaper bags); Motion Picture Ass'n of Am., Inc., v. Respect Sportswear, Inc., 83 U.S.P.Q.2d 1555, 1564 (T.T.A.B. 2007) (denying the registration of "RATED R SPORTSWEAR" lest consumers believe the Motion Picture Association of America also monitors apparel); see also Dogan \& Lemley, supra note 4, at 478 n.27, 484-85 (citing trademark cases, many successful, enjoining parodies); Lemley \& McKenna, supra note 9, at 417-20 (describing successful cases against defendants using trademarks in artistic, parodic, and other non-confusing ways); Xiyin Tang, Against Fair Use: The Case for a Genericness Defense in Expressive Trademark Uses, 101 IowA L. REV. 2021, 2039 (2016) (explaining that the current doctrine privileges only certain types of expressive uses, notably parodies).

14. See, e.g., William McGeveran, The Imaginary Trademark Parody Crisis (And the Real One), 90 WASH. L. REv. 713, 728-30 (2015) (explaining that after Campbell protected a parodic use of a copyrighted work, "courts now favor [i.e., allow] trademark parodies," too).

15. See, e.g., Glynn S. Lunney, Jr., Two-Tiered Trademark, 56 Hous. L. REV. 295, 297 (2018) ("[T] he party that cannot afford the high and increasing cost of participation in the trademark system loses . . . not because justice . . . dictates that they lose[,] but because they cannot afford to participate in the system. . . . [R]esolution will turn solely on which party can afford to litigate."); Leah Chan Grinvald, Shaming Trademark Bullies, 2011 WIS. L. REV. 625, 628-30, 652 (explaining how the costs of rebuffing "trademark bullies" makes "ceasing to use the trademark at stake without a battle" perhaps the least expensive option); William McGeveran, supra note 9, at 52 ("The lethal combination of uncertain standards with lengthy and costly litigation creates a classic chilling effect upon the unlicensed use 
owners tend to lose most cases against political and social speech, they still end up shutting down quite a bit of socially valuable speech that the law is not intended to target. These efforts likely deter even more protected speech from ever occurring, particularly because trademark owners are aggressively sending threatening cease-and-desist letters even when they don't file suit. ${ }^{16}$

When pressed as to why they bring weak trademark claims against protected speech, or even against extremely remote marks, trademark owners frequently fall back on the justification that they have an obligation to police their trademarks against potentially infringing uses. ${ }^{17}$ If they don't aggressively enforce their marks, they worry that the value of their marks will be weakened by multiple,

of trademarks to facilitate speech, even when such uses are perfectly lawful."); Kenneth L. Port, Trademark Extortion: The End of Trademark Law, 65 WASH. \& LEE L. REV. 585, 588-91 (2008) (describing trademark "strike suits" that would likely lose on the merits but that, even when not litigated, accomplish the mark owner's goal of expanding the effective scope of her mark); Deven R. Desai \& Sandra L. Reirson, Confronting the Genericism Conundrum, 28 CARDOZO L. REV. 1789, 1839 (2007) ("Typically, the threat of litigation alone (even when ever so lightly implied) by a corporate giant is sufficient to dissuade a person from making fair use of a trademark."); cf. James Gibson, Risk Aversion and Rights Accretion in Intellectual Property Law, 116 YALE L.J. 882, 913 (2007) (“[T]rademark users who could mount a decent defense against an infringement claim [often will] nevertheless choose to seek a license.").

16. See, e.g., Leah Chan Grinvald, Policing the Cease-and-Desist Letter, 49 U.S.F. L. REV. 411, 411-12 (2015) (noting that 97\% of disputes never result in a lawsuit, much less a judgment, and proposing ways to regulate abusive cease-anddesist letters); Irina D. Manta, Bearing Down on Trademark Bullies, 22 FordHAM Intell. Prop., Media \& EnT. L.J. 853, 854-57 (2012); William McGeveran, The Trademark Fair Use Reform Act, 90 B.U. L. REV. 2267, 2269 (2010) (“For every speaker who fights back in court, countless others cautiously back away."); Elizabeth L. Rosenblatt, Rethinking the Parameters of Trademark Use in Entertainment, 61 FLA. L. REV. 1011, 1014 (2009) ("Ultimately, current law creates a doctrinally imbalanced system that chills speech, increases the transaction costs of content creation, and disproportionately harms small or independent content creators.").

17. See William T. Gallagher, Trademark and Copyright Enforcement in the Shadow of IP Law, 28 SANTA Clara COMPUTER \& High TeCH. L.J. 453, 490-91 n.115 (2012) (recounting interviews with practitioners who offer this justification for threatening to sue others even when the merits of their claim are weak and describing case law); Port, supra note 15, at 587 (citing Wallpaper Mfrs., Ltd. v. Crown Wallcovering Corp., 680 F.2d 755, 766 (C.C.P.A. 1982)) (“Of course, trademark holders must police their trademarks or suffer the fate of a court subsequently finding that trademark holders acquiesced to infringing uses or that the mark now lacks distinctiveness."). 
conflicting uses..$^{18}$ In extreme cases, they worry that they will lose their marks altogether by having courts deem them generic or abandoned or else lose the right to enforce them through laches. ${ }^{19}$

It is tempting to dismiss these claims as cynical efforts to justify conduct that is in fact intended to deter and suppress protected speech the trademark owner simply doesn't like. And in many cases, that is probably the explanation. There doesn't seem to be any case punishing a trademark owner for failing to police a mark against the sorts of speech with which I am concerned here. Indeed, I didn't find a single case holding a mark abandoned or otherwise lost solely for failure to police the mark at all. All the cases considering the issue point in the opposite direction. ${ }^{20}$ Further, policing alone is generally insufficient to save a mark from becoming generic. ${ }^{21}$ Courts have generally considered policing (or lack thereof) as just one piece of evidence when evaluating strength of the mark, likelihood of confusion, genericide, and laches. It is tempting, therefore, to view the whole requirement of trademark policing as a myth, rather like the received

18. Jeremy Sheff refers to this as fear-driven enforcement. Jeremy N. Sheff, Fear and Loathing in Trademark Enforcement, 22 FordHAM InTELl. Prop., MediA, \& ENT. L.J. 873, 874-77 (2012).

19. See Grupo Gigante S.A. de C.V. v. Dallo \& Co., 391 F.3d 1088, 1101-02 (9th Cir. 2004) (setting out the test for laches and stating that "[c]ompanies expecting judicial enforcement of their marks must conduct an effective policing effort" (emphasis omitted) (quoting Am. Int'l Grp., Inc. v. Am. Int'l Bank, 926 F.2d 829, 834 (9th Cir. 1991) (Kozinski, J., dissenting))); Desai \& Rierson, supra note 15, at 1791, 1834-42 (discussing the perceived need to police infringement to avoid genericide).

20. For cases rejecting abandonment claims based on failure to police, see, for example, Palm Bay Imports, Inc. v. Veuve Clicquot Ponsardin Maison Fondee En 1772, 396 F.3d 1369, 1373 (Fed. Cir. 2005) (finding no abandonment despite at least five different alcoholic beverages that use the term VEUVE); Hermes Int'l $v$. Lederer de Paris Fifth Avenue, Inc., 219 F.3d 104, 110 (2d Cir. 2000); Navajo Nation v. Urban Outfitters, Inc., 212 F. Supp. 3d 1098, 1105 (D.N.M. 2016) (“[T]he existence of thirdparty infringers does not by itself constitute abandonment of a mark where the mark owner does not consent to its use, provided that the mark does not lose all ability to identify the senior user."); and Patsy's Italian Rest., Inc. v. Banas, 508 F. Supp. 2d 194, 212 (E.D.N.Y. 2007).

21. See Anti-Monopoly, Inc. v. Gen. Mills Fun Grp., Inc., 684 F.2d 1316, 1322 (9th Cir. 1982) ("[Policing], however, is not of itself sufficient to create legally protectable rights."); Hickory Farms, Inc. v. Snackmasters, Inc., 509 F. Supp. 2d 716, 723 (N.D. Ill. 2007) ("[P]olicing is of no consequence to a resolution of whether a mark is generic.") (quoting Murphy Door Bed Co. v. Interior Sleep Systems Inc., 874 F.2d 95, 101 (2d Cir. 1989))); see also Pilates, Inc. v. Current Concepts, Inc., 120 F. Supp. 2d 286, 306 (S.D.N.Y. 2000). 
(but inaccurate) wisdom that you shouldn't let your mark be used as a verb for fear that it will be declared generic. ${ }^{22}$

But the reality is a bit more complicated. A failure to police can be a factor leading to genericide, even if it is not itself determinative. ${ }^{23}$ Policing can influence the scope of protection. Some courts have found trademarks to be stronger because of vigorous efforts to police the mark against infringing uses..$^{24}$ On the flip side, a number of courts have found the strength of the mark decreased due to the presence of a number of other, similar marks, and the mark thus entitled to only a narrow scope of protection. ${ }^{25}$ While that is not specifically a finding

22. See Rose A. Hagan, The Myths of Genericide, 22 IPL NewsL. 13, 13 (2004) (finding that no trademark in history has been held generic merely because it was used as a verb). That myth was dispelled for good, I suspect, in Elliott v. Google Inc., 860 F.3d 1151, 1155 (9th Cir. 2017).

23. See BellSouth Corp. v. DataNational Corp., 60 F.3d 1565, 1570 (Fed. Cir. 1995) ("While the 'Walking Fingers' logo may once have been a strong candidate for trademark protection, through common usage by virtually all classified directory publishers it can no longer be understood to represent a source of the directories."); Malaco Leaf, AB v. Promotion in Motion, Inc., 287 F. Supp. 2d 355, 363 (S.D.N.Y. 2003) ("This Court agrees that the generic design of Malaco's Swedish Fish, along with extensive third party use of the design and Malaco's failure to police infringing third-party uses, renders the Swedish Fish design generic and unprotectable.”).

24. See Morningside Grp. Ltd. v. Morningside Capital Grp., L.L.C., 182 F.3d 133, 139 (2d Cir. 1999) ("[T]he successful policing of a mark adds to its strength to the extent that it prevents weakening of the mark's distinctiveness in the relevant market."); Abraham v. Alpha Chi Omega, 781 F. Supp. 2d 396, 419 (N.D. Tex. 2011); Cullman Ventures, Inc. v. Columbian Art Works, Inc., 717 F. Supp. 96, 124 (S.D.N.Y. 1989).

25. See, e.g., CareFirst of Maryland, Inc. v. First Care, P.C., 434 F.3d 263, 270 (4th Cir. 2006) ("This evidence of extensive third-party use also demonstrates that CareFirst's mark lacks commercial strength in many parts of the country."); Supreme Assembly, Order of Rainbow for Girls v. J.H. Ray Jewelry Co., 676 F.2d 1079, 1083-84 (5th Cir. 1982) (treating an organization's historical lack of control over its marks as important in determining that there was no likelihood of confusion as to the source of the mark); Sun Banks of Fla., Inc. v. Sun Federal Sav. \& Loan Ass'n, 651 F.2d 311, 316 (5th Cir. 1981) (indicating that in 1976, there were over 4400 businesses registered with the word "Sun" in their names); Amstar Corp. v. Domino's Pizza, Inc., 615 F.2d 252, 265 (5th Cir. 1980) (reasoning that "[a] trademark owner that strongly believed its customers were being deceived would hardly have remained idle for such an extended period of time," and so narrowing Amstar's DOMINO mark to sugar field); Armstrong Cork Co. v. World Carpets, Inc., 597 F.2d 496, 505 (5th Cir. 1979) (reasoning that the fact eighty-five firms using WORLD in carpet retailing and manufacturing "militates against the finding of likelihood of confusion"); Fuel Clothing Co. v. Nike, Inc., 7 F. Supp. 3d 594, 611-13 (D.S.C. 2014) (reasoning that the fact that over 1,000 marks included "Fuel" weakened the strength of plaintiff's mark, and granting summary judgment to defendant on most claims); Trs. of Columbia Univ. v. Columbia/HCA Healthcare Corp., 964 F. Supp. 733, 74445 (S.D.N.Y. 1997) (finding "Columbia" relatively weak as mark in healthcare 
that failure to police narrows the scope of a trademark owner's rights, it provides a significant legal incentive to police because failure to do so can allow similar marks to proliferate and cabin the trademark owner's rights.

Further, while policing alone won't prevent a mark from becoming generic, some courts that have rejected claims of genericide have pointed to the absence of competing uses of the mark as a factor, and that absence sometimes results from aggressive enforcement. ${ }^{26}$

Policing is also relevant to laches. Courts will not enforce a trademark if the plaintiff has unreasonably delayed in filing suit and the defendant is prejudiced as a result. ${ }^{27}$ Unreasonable delay is measured from the time of either actual or constructive knowledge of the competing use. ${ }^{28}$ The constructive knowledge standard effectively imposes on a trademark owner the duty to be aware of potential infringers, and probably to take some action, because a trademark owner that should have been aware of a use won't avoid laches because of her ignorance. ${ }^{29}$

industry because of substantial third-party use by hospitals, healthcare services, and institutions).

26. See, e.g., Pfizer Inc. v. Sachs, 652 F. Supp. 2d 512, 521 (S.D.N.Y. 2009) ("Pfizer's active policing efforts also refute Defendants' claim that the Viagra Marks are generic.”); Frito-Lay, Inc. v. Bachman Co., 704 F. Supp. 432, 440 (S.D.N.Y. 1989) ("[D]ue to Frito-Lay's vigorous policing efforts . . . [defendant] can offer no evidence of widespread industry use.").

27. See, e.g., Hot Wax, Inc. v. Turtle Wax, Inc., 191 F.3d 813, 824 (7th Cir. 1999) (holding laches applied because "Hot Wax sat idly by and chose not to challenge" while Turtle Wax invested in the mark for a ten- to twenty-year period); Kason Indus., Inc. v. Component Hardware Grp., Inc., 120 F.3d 1199, 1203 (11th Cir. 1997) (setting out test for doctrine of laches in trademark, including delay without excuse); Sara Lee Corp. v. Kayser-Roth Corp., 81 F.3d 455, 461 (4th Cir. 1996) ("In a trademark case, courts may apply the doctrine of estoppel by laches to deny relief to a plaintiff who, though having knowledge of an infringement, has, to the detriment of the defendant, unreasonably delayed in seeking redress.").

28. Kason, 120 F.3d at 1203. But cf. What-A-Burger of Virginia, Inc. v. Whataburger, Inc., 357 F.3d 441, 449 (4th Cir. 2004) ("Instead of focusing on when the trademark owner first knew that another party was using its mark, the court should be trying to determine the time at which the use became infringing and the time at which the owner should have known it ....").

29. See E-Systems, Inc., v. Monitek, Inc., 720 F.2d 604, 607 (9th Cir. 1983) ("Plaintiff ought to have discovered defendant's use sooner had it been diligently seeking to enforce its mark."); Black Diamond Sportswear, Inc. v. Black Diamond Equip., Ltd., No. 06-3508-cv, 2007 WL 2914452, at *3 (2d Cir. Oct. 5, 2007) ("A trademark owner is 'chargeable with such knowledge as he might have obtained upon [due] inquiry."' (alteration in original) (quoting Polaroid Corp. v. Polarad Elecs. Corp., 182 F. Supp. 350, 355 (E.D.N.Y. 1960))); accord Cybergun, S.A. v. Jag Precision, No. 2:12-cv-00074-APG-GWF, 2014 WL 7336074, at *3 (D. Nev. 
The received wisdom that trademark owners must police infringement of their marks, then, is overstated but contains important kernels of truth. Owners don't have to police their marks. But doing so helps in various ways. Lawyers who advise trademark owners to police aren't wrong, at least not entirely. The issue is gray, not black and white.

\section{POLICING PARODIES}

The desirability of stopping obvious acts of infringementcounterfeiting or the adoption of the same mark by a direct competitor-does not mean that trademark owners must or should sue anyone who uses their mark or anything like it. And as noted above, overreaching by trademark owners who bring claims against parodists or critics rather than their commercial competitors causes harm to the world. We should discourage such overreach. The question is how.

One obvious response is for courts to make clear that policing one's mark against infringing uses doesn't require policing against non-infringing uses like parody, criticism, non-trademark use, ${ }^{30}$ or

Dec. 19, 2014); Brown v. Sixteen, Inc., No. 02 Civ. 4630(DAB), 2009 WL 1159161, at *5 (S.D.N.Y. Apr. 28, 2009); Saul Zaentz Co. v. Wozniak Travel, Inc., 627 F. Supp. 2d 1096, 1114 (N.D. Cal. 2008) (explaining "plaintiff is charged with constructive knowledge"); Miller v. Glenn Miller Prods., 318 F. Supp. 2d 923, 943 (C.D. Cal. 2004); cf. Grupo Gigante S.A. de C.V. v. Dallo \& Co., 391 F.3d 1088, 1101-02 (9th Cir. 2004) (stating a rule that "[c]ompanies expecting judicial enforcement of their marks must conduct an effective policing effort," though in a case where plaintiff did not claim ignorance of defendant's uses (emphasis omitted) (quoting Am. Int'l Group, Inc. v. Am. Int'l Bank, 926 F.2d 829, 834 (9th Cir. 1991) (Kozinski, J., dissenting))).

30. This is an argument I have made elsewhere. See Dogan \& Lemley, supra note 4 , at 477-80 \& nn.26-28 (arguing for use of the mark as a brand in order to be actionable infringement and citing court opinions adopting this trademark use doctrine often by referencing the "in connection with" or the "use in commerce" language of the Lanham Act); Stacey L. Dogan \& Mark A. Lemley, Grounding Trademark Law Through Trademark Use, 92 IowA L. REV. 1669, 1682 (2007) ("Strictly speaking, trademark infringement should require not only that a defendant be using the mark to promote its own products or services but also that it be using it 'as a mark'-i.e., to indicate the source or sponsorship of those products or services."). As examples of courts implicitly adopting a trademark use doctrine, see Louis Vuitton Malletier $v$. Burlington Coat Factory Warehouse Corp., 426 F.3d 532, 538-39 (2d Cir. 2005) ("[T] he Lanham Act requires a court to analyze the similarity of the products in light of the way in which the marks are actually displayed in their purchasing context" because the "Act seeks to eliminate the confusion that is created in the marketplace by the sale of products bearing highly similar marks."); and Interactive Prods. Corp. v. A2Z Mobile Office Sols. Inc., 326 F.3d 687, 698 (6th Cir. 2003) ("Because post-domain paths do not typically signify source, it is unlikely that the presence of another's trademark in a post-domain path of a URL would ever violate trademark 
nominative use of the mark to refer to the trademark owner's own goods. ${ }^{31}$ This seems easy, indeed almost tautological: Trademark owners don't have to sue people for things that don't actually violate their rights. I suppose some trademark owners might (wrongly) think such uses are infringing and therefore that they have to pursue parodists and nominative fair users even if they don't want to. But the law already provides that trademark owners are not required to act against every infringing use - acting against the most damaging uses is sufficient. ${ }^{32}$ Even if a trademark owner thought a parody was infringing, that infringement would surely not be the core sort the policing requirement is directed against. Parodies, nominative uses, and the like don't pose any of the risks that motivate policing. They won't make a mark generic because they refer back to and therefore strengthen rather than weaken the connection between the mark and its owner. ${ }^{33}$ And they won't weaken a mark by crowding the field because they aren't competitive uses. At most, deciding not to sue

law."). As an example of a court implicitly rejecting this trademark use doctrine, see Rosetta Stone Ltd. v. Google Inc., 676 F.3d 144, 151-52, 161-63 (4th Cir. 2012) (reversing summary judgment for defendant where defendant used trademark only as a keyword to identify when to place an ad for competing product and not in the ad itself).

31. See, e.g., Int'l Info. Sys. Sec. Certification Consortium, Inc. v. Security Univ., L.L.C., 823 F.3d 153 (2d Cir. 2016); Century 21 Real Estate Corp. v. Lendingtree, Inc., 425 F.3d 211, 232 (3d Cir. 2005); New Kids on the Block v. News Am. Publ'g, 971 F.2d 302, 306-07 (9th Cir. 1992) (holding use of band's name in newspaper poll was nominative under new test); see also Dogan \& Lemley, supra note 4, at 505-08 (discussing nominative fair use doctrine and cases); McGeveran, supra note 9, at 88-97 (arguing that the nominative fair use doctrine fails to serve as an adequate "early screening mechanism").

32. See, e.g., Cullman Ventures, Inc. v. Columbian Art Works, Inc., 717 F. Supp. 96, 127 (S.D.N.Y. 1989) (noting approvingly that plaintiff policed the two most damaging uses of its mark by others); Elizabeth Taylor Cosmetics Co. v. Annick Goutal, S.A.R.L., 673 F. Supp. 1238, 1248 (S.D.N.Y. 1987) (explaining that "a trademark owner is not required to act against every infringing use no matter how inconsequential"); Playboy Enters., Inc. v. Chuckleberry Publ'g, Inc., 486 F. Supp. 414, 422-23 (S.D.N.Y. 1980) ("The owner of a mark is not required to police every conceivably related use ....").

33. See, e.g., Louis Vuitton Malletier S.A. v. Haute Diggity Dog, L.L.C., 507 F.3d 252, 260-61 (4th Cir. 2007) (holding plush "Chewy Vuitton" puppy toys to be a non-infringing parody of bags with Louis Vuitton marks because they allow consumers "to perceive the target of the parody, while simultaneously allowing them to recognize the changes to the mark that make the parody funny or biting"); Jordache Enters. v. Hogg Wyld, Ltd., 828 F.2d 1482, 1489-90 (10th Cir. 1987) (holding that "it is not likely that public identification of JORDACHE with the plaintiff will be eroded [by defendant's parody "Lardashe"]; indeed, parody tends to increase public identification of a plaintiff's mark with the plaintiff"). 
non-infringing parodists might raise a laches defense if a trademark owner later decides to sue non-infringing parodists. But so what? They weren't going to win that suit anyway. ${ }^{34}$

It can't hurt for courts to make clear that any policing obligation does not extend to efforts to stop non-infringing uses like parodies. But for the reasons just mentioned, trademark owners - at least those advised by savvy counsel - should be unlikely to think they have to sue parodists in order to protect their mark. A more likely explanation is that they want to stop the parodies, either by persuading a court to do so or by using the cost and uncertainty of litigation to drive small users out of business. ${ }^{35}$ And if that's their goal, just telling them they don't need to do it won't stop them.

We need better reasons for trademark owners to lay off parodies and other socially beneficial uses of trademarks. Prior scholars have suggested sticks: penalties for frivolous lawsuits or for dubious threat letters, greater fee shifting, declaring the mark expressively generic, and the like. ${ }^{36}$ Those are probably good ideas, though they may not protect the people who most need protecting - those who fold up shop in response to a scary-looking cease-and-desist letter because they don't know any better or can't afford to vindicate their rights.

\section{McGeveran, supra note 9, at 52 .}

35. See Chan Grinvald, supra note 15, at 651 (summarizing the competitive benefit to mark owners from controlling their trademark while imposing costs on other users who may be their rivals or potential rivals); Yvette Joy Liebesman \& Benjamin Wilson, The Mark of a Resold Good, 20 Geo. MASON L. REv. 157, 163-64 (2012) (describing how small resellers of products may close rather than face litigation from those who own trademarks related to those products). Sheff refers to this as loathingbased as opposed to fear-based enforcement. See Sheff, supra note 18, at 875-77.

36. See, e.g., Chan Grinvald, supra note 15, at 669 (proposing consumersupported shaming); Chan Grinvald, supra note 16, at 414-15 (proposing the regulation of cease-and-desist letters); Leah Chan Grinvald, Social Media, Sharing, and Intellectual Property Law, 64 DePAUL L. REV. 1045, 1072-73 (2015) (suggesting better access to low-cost legal services); Leah Chan Grinvald, Charitable Trademarks, 50 AKRON L. REV. 817, 854, 860 (2016) (suggesting heightened pleading requirements and social shaming, particularly against overreaching non-profits); Stacey Dogan, Bullying and Opportunism in Trademark and Right of Publicity Law, 96 B.U. L. REV. 1293, 1317-18 (2016); Manta, supra note 16, at 858-62 (proposing judicial sanctions and fee-shifting), 862-63 (proposing measures akin to anti-SLAPP (Strategic Lawsuit Against Public Participation) protections); Gallagher, supra note 17, at 495-96; Kiser, supra note 1, at 540 (arguing for a legal right for fan sites to use brands); $c f$. Paul J. Heald, Payment Demands for Spurious Copyrights: Four Causes of Action, 1 J. InTELL. PROP. L. 259, 262 (1994) (assessing, in the copyright context, approaches to combating wrongful copyright infringement claims through actions based in breach of warranty, unjust enrichment, fraud, and false advertising); see also Dreyfuss, supra note 1, at 399; Tang, supra note 13, at 2028-29. 
My goal here is to suggest a carrot, not a stick. If we want trademark owners to be motivated not to sue parody and criticism sites, we should make the existence of those sites a good rather than a bad thing for trademark owners. I propose that the law view the existence of parody and criticism of a brand as affirmative evidence that the brand is famous and maybe even treat it as a requirement for fame.

Brands want to be famous. ${ }^{37}$ Famous trademarks are strong marks entitled to a broader scope of protection against likely consumer confusion. ${ }^{38}$ Further, only famous marks are entitled to extra protection against trademark dilution even in the absence of consumer confusion. ${ }^{39}$ Once the Federal Trademark Dilution Act was passed in 1995, many companies sought and were granted famous status for marks that were not actually very famous. ${ }^{40}$ Congress raised the standard of fame in the Trademark Dilution Reform Act of 2006. Under that narrowed definition, "a mark is famous if it is widely recognized by the general consuming public of the United States as a designation of source of the goods or services of the mark's owner." ${ }^{41}$ Since 2006, local fame and fame in certain markets no longer count, and even well-known marks like those of Coach and the University of Texas Longhorns have been held not to qualify. ${ }^{42}$

Fame is likely to be particularly relevant in cases of parody and other forms of protected speech about trademarks. Parodies, satire, and

37. On the value of fame to trademark owners, see Leah Chan Grinvald, Contracting Trademark Fame?, 47 Loy. U. CHI. L.J. 1291, 1305-11 (2016).

38. See Nabisco, Inc. v. P.F. Brands, Inc., 191 F.3d 208, 214-17 (2d Cir. 1999) (setting out special statutory protections accorded famous marks and explaining their intent).

39. See 15 U.S.C. $§ 1125(c)(2012)$.

40. See, e.g., Times Mirror Magazines, Inc. v. Las Vegas Sports News, L.L.C., 212 F.3d 157, 169-70 (3d Cir. 2000) (affirming "The Sporting News" famous in sports context over vigorous dissent); Ringling Bros.-Barnum \& Bailey Combined Shows, Inc. v. Utah Div. of Travel Dev., 955 F. Supp. 605, 605-06 (E.D. Va. 1997) (finding "Greatest Show on Earth" to be famous); Am. Exp. Co. v. CFK, Inc., 947 F. Supp 310, 312 (E.D. Mich. 1996) (finding "Don't Leave Home Without It" to be a famous mark). In Appendix A, I contrast examples like these with others found famous after Congress raised the fame standard by passing the Trademark Dilution Reform Act of 2006. See infra app. A.

41. $§ 1125(\mathrm{c})(2)(\mathrm{A})$.

42. Coach Servs., Inc., v. Triumph Learning L.L.C., 668 F.3d 1356, 1372 (Fed. Cir. 2012) (finding Coach not famous for dilution purposes); Bd. of Regents, Univ. of Texas Sys. ex rel. Univ. of Texas at Austin v. KST Elec., Ltd., 550 F. Supp. 2d 657, 678-79 (W.D. Tex. 2008) (finding the Texas Longhorn logo not famous). I present a full list of marks adjudicated famous and not famous under both the old and the new law in Appendix A. 
criticism naturally target or employ well-known brands; making fun of a trademark no one has ever heard of seems a bootless enterprise, and a satire based on a meme no one understands won't be very effective ${ }^{43}$ Similarly, companies have a greater need to talk about famous marks in order to compare their goods to the market leader or explain why their products are, say, compatible with Apple's iPhone. And the public as a whole may appropriate a mark for cultural conversation, but it is more likely to do so if the mark is famous and therefore well understood. ${ }^{44}$

Further, each of these types of uses reinforces rather than dilutes the significance of the brand in question. A parody or satire only works because people get the joke - because they simultaneously recognize the reference to the brand and understand that the parody is not the brand. ${ }^{45}$ The point of nominative fair uses - comparative advertising, discussing your relationship with the branded product, and the like-

43. See, e.g., Dr. Seuss Enters., L.P. v. Penguin Books USA, Inc., 109 F.3d 1394, 1400-01, 1406 (9th Cir. 1997) (satirizing the O.J. Simpson trial through a Dr. Seuss-styled book); Louis Vuitton Malletier, S.A. v. Hyundai Motor Am., No. 10 Civ. 1611(PKC), 2012 WL 1022247, at*1 (S.D.N.Y. Mar. 22, 2012) (satirizing luxury via a one-second shot of a basketball covered in Louis Vuitton marks in a Hyundai commercial); Coca-Cola Co.v. Gemini Rising, Inc., 346 F. Supp. 1183, 1193 (E.D.N.Y. 1972) (parodying "Enjoy Coca-Cola" via an "Enjoy Cocaine" poster); $c f$. Campbell v. Acuff-Rose Music, Inc., 510 U.S. 569, 586 (1994) (underscoring that "parodies almost invariably copy publicly known, expressive works" in a copyright context).

44. Barbie, for instance, has been appropriated by several artists using it as a shorthand to comment on society. See Mattel, Inc. v. Walking Mountain Prods., 353 F.3d 792, 796 (9th Cir. 2003) (discussing "Barbie Enchiladas" visual art); Mattel, Inc. v. MCA Records, Inc., 296 F.3d 894, 902 (9th Cir. 2002) (discussing "The Barbie Girl" song). See generally Dreyfuss, supra note 1 (explaining how trademarks function as "ideograms" and examining the law's difficulty in policing and protecting such uses appropriately).

45. Successful parodies are permitted not least because they do not confuse consumers. See Louis Vuitton Malletier S.A. v. Haute Diggity Dog, L.L.C., 507 F.3d 252, 260-261 (4th Cir. 2007) (reasoning "an effective parody will actually diminish the likelihood of confusion" because it enables audiences "to perceive the target of the parody, while simultaneously allowing them to recognize the changes to the mark that make the parody funny or biting"); L.L. Bean, Inc. v. Drake Publishers, Inc., 811 F.2d 26, 34 (1st Cir. 1987) ("[A] trademark parody . . . juxtapose[es] the irreverent representation of the trademark with the idealized image created by the mark's owner."); cf. Campbell, 510 U.S. at 599 (explaining that the successful parodist makes an original statement about something already popularly known). By contrast, unsuccessful parodies may infringe precisely because they confuse consumers. See Dr. Seuss Enters., 109 F.3d at 1405 (making this point); see also Charles E. Colman, Trademark Law and the Prickly Ambivalence of Post-Parodies, 163 U. PA. L. REV. ONLINE 11, 41-42 (2014) (indicating the same). 
is to use the trademark to refer not to your own goods but to the trademark owner's. Similarly, trademarks in expressive products are there because the author wants to talk about the trademarks. They too reinforce the semantic connection between the brand and the product it refers to. ${ }^{46}$ So it makes sense to think that famous marks are the ones most likely to attract parodies and other speech-related uses and that those uses reinforce rather than dilute the significance of the mark as a referent for the trademark owner's goods in the minds of the public. For both reasons, the presence of parodies and other referential uses surely correlates with fame.

Notably, the most famous brands are also the most likely to sue parodists. I collected data on trademark complaints involving both marks held famous under the 2006 Trademark Dilution Act (TDRA) and marks held not famous under the same statute. ${ }^{47}$ Owners of trademarks held famous under the higher TDRA standard filed 562 trademark suits involving those brands between 2007 and 2017. Of those cases, seventeen were brought against uses alleged to be parodies. By contrast, companies owning marks held not famous filed 561 suits involving those marks, none against parodists. But almost all of those suits were filed by one company - Coach, which brought 540 suits. Excluding Coach, other non-famous brands brought only twenty-one lawsuits, none involving parodies. ${ }^{48}$

I don't mean to make too much of this data. It includes only the actual marks held famous under the new law, not marks that are surely famous under both laws (e.g., Barbie, Google, and the Louis Vuitton "LV" logo). It excludes cease-and-desist letters that never made it to court and court cases that never made it to decision. And it excludes at least some suits against parodies by marks that are probably famous but whose fame was not in serious question in the case. ${ }^{49}$ So one should not conclude from this that people only parody famous marks.

46. See Rebecca Tushnet, Gone in Sixty Milliseconds: Trademark Law and Cognitive Science, 86 TEX. L. REV. 507, 516-17, 525-27, 537 (2008) (summarizing and challenging the view that unauthorized uses tend to weaken or replace a mark's association with a product, citing research showing "exposure to near variants or uses in other contexts makes the trademark more familiar and thus more easily retrieved from memory," much as "Tiffany's-the-restaurant may make us think of Tiffany'sthe-jeweler when we are at lunch thinking of gifts for Mother's Day").

47. And by "I collected," I mean my research assistants did all the hard work.

48. The complete list of cases we collected is available on request.

49. See, e.g., Louis Vuitton Malletier, S.A. v. My Other Bag, Inc., 674 F. App'x 16, 19 (2d Cir. 2016) (affirming summary judgment for defendant maker of "My Other Bag" referencing Louis Vuitton bag without explicitly assessing whether Louis Vuitton was, as it must be for federal dilution statute to apply, famous); Louis 
Nonetheless, three things stand out. First, famous mark owners seem to be the only ones targeting parodies. Second, only a minority of famous mark owners in my study filed any claims against parodies at all. Many famous brands, even those who do plenty of enforcement, sue only traditional infringers or counterfeiters. That hasn't prevented their marks from being declared famous. Third, even famous mark owners who do target parodies bring only a small fraction of their suits against parodies, meaning stopping parodies isn't their ordinary form of policing.

All of this suggests that encouraging famous mark owners to celebrate (or at least tolerate) parodies, satire, and other expressive uses is likely to be effective in targeting the worst cases of trademark overreach. Companies don't need to target parodies or other expressive uses to survive or to thrive.

The change I propose is simple: Courts should consider the existence, number, and prominence of unauthorized parodies, satires, or other expressive and referential uses of a mark directed at the general public as evidence tending to show that the mark is famous for both dilution and likelihood of confusion purposes, and the absence of such uses as tending to show that the mark is not famous and not as strong. ${ }^{50}$ Considering parodies as a factor favoring fame is straightforward to do under the judicially created likelihood of confusion test, which considers the strength and renown of the mark in assessing confusion. It is also straightforward under the existing dilution statute, which provides that "[i]n determining whether a mark possesses the requisite degree of recognition, the court may consider all relevant factors." ${ }^{11}$ The existence of expressive and referential uses specifically seems relevant to the "extent... of advertising and publicity of the mark ... by . . . third parties," one of the elements for

Vuitton Malletier, S.A. v. Hyundai Motor Am., No. 10 Civ. 1611(PKC), 2012 WL 1022247, at*1 (S.D.N.Y. Mar. 22, 2012) (finding that a one-second shot in Hyundai's Super Bowl commercial that showed a basketball covered in interlocking LV marks infringed and diluted Louis Vuitton's trademark). Louis Vuitton still had to prove fame, of course, but it was not in serious question. See id. at *2.

50. This is consistent with Lisa Ouellette's suggestion that we judge trademarks in part by how people actually treat and use them in Internet searches. See Lisa Larrimore Ouellette, The Google Shortcut to Trademark Law, 102 CALIF. L. REV. 351, 372 (2014). Alexandra Roberts makes a parallel suggestion - that public talk about marks (which can include parodies and other expressive uses) is evidence of secondary meaning of those marks. See Alexandra J. Roberts, Mark Talk, https://papers.ssrn.com/sol3/papers.cfm?abstract_id=3239734 (Univ. of N.H. Sch. of Law, Working Paper 2018).

51. 15 U.S.C. $\S 1125(c)(2)(A)(2012)$. 
fame. ${ }^{52}$ My proposal should encourage trademark lawyers to advise their clients to let such uses be. Trademark owners don't need to police expressive uses even today, and my approach would give them a reason not to.

We could go further, making the existence of parodies or expressive uses a requirement for fame. That would have some advantages, including changing the incentives of companies that are unquestionably famous. But that stronger version would require Congress to change the dilution statute. ${ }^{53}$

52. Id.

53. There is a robust debate on whether dilution law is a good idea at all. Many are skeptical. See Barton Beebe, Symposium Review, The Continuing Debacle of U.S. Antidilution Law: Evidence from the First Year of Trademark Dilution Revision Act Case Law, 24 Santa Clara Computer \& High Tech. L.J. 449, 450 (2007) (reviewing a year's cases and finding the dilution cause of action used redundantly alongside infringement cause of action, suggesting its limited value); Barton Beebe et al., Testing for Trademark Dilution in Court and in the Lab, 86 U. CHI. L. REV. (forthcoming 2019) (casting doubt on evidence of dilution by blurring); Kenneth L. Port, The Commodification of Trademarks: Some Final Thoughts on Trademark Dilution, 46 HoFSTRA L. REV 669, 669 (2017) (arguing that the Federal Trademark Dilution Act "has not been the panacea for famous marks it was intended to be and has created perverse unintended consequences"); Jeremy N. Sheff, Finding Dilution 1 (St. John's Sch. of Law, Working Paper No. 18-002, 2018) (“[W]hen we finally cut our way through the fog we will find that dilution is simply not there. It is, at bottom, an entirely empty concept...."); Tushnet, supra note 46, at 568 (concluding dilution is not well-supported by cognitive science and an "otherwise ... obscure concept"). Others defend dilution law. See Jerre B. Swann, An Interdisciplinary Approach to Brand Strength, 96 TRADEMARK REP. 943, 975-76 (2006); Jerre B. Swann, An Intuitive Approach to Dilution, 89 Trademark ReP. 907, 907 (1999). For an overview of dilution doctrine and the theory that underlies it - or not - see Stacey L. Dogan \& Mark A. Lemley, What the Right of Publicity Can Learn from Trademark Law, 58 STAN. L. REV. 1161, 1197-1200 (2006). There is also some question of whether it is constitutional after Matal v. Tam, which invalidated one of the trademark statute's restrictions on speech for being insufficiently narrow for the purposes of facilitating commerce. See Matal v. Tam, 137 S. Ct. 1744, 1764-65 (2017) (holding Lanham Act's requirement that the Patent and Trademark Office deny registration to disparaging marks violated First Amendment because it was not "narrowly drawn" to bar only commercially disruptive marks); see also Lisa P. Ramsey, Free Speech Challenges to Trademark Law After Matal v. Tam, 56 Hous. L. REV. 401, 401-02 (2018).

I am sensitive to the concern that my proposal may enable companies to use the dilution statute when we might be better off not having one at all. But we have dilution law, and in this paper I take it for granted. Further, even if we were to eliminate dilution law, fame still matters to infringement law, because famous marks arerightly or wrongly_ given broader protection than less famous marks. Cf. Barton Beebe \& C. Scott Hemphill, The Scope of Strong Marks: Should Trademark Law Protect the Strong More Than the Weak?, 92 N.Y.U. L. REV. 1339, 1339 (2017) (arguing that strong marks are actually less likely to be confused with imitations). So 
Indeed, one might worry about the opposite problemcompanies trying to encourage or fake parodies or other expressive uses to meet the new requirement of fame. Courts should ensure that the uses in question are independent and unauthorized. For my proposal to work, a company should not be able to point to expressive uses of its work if it also sues or threatens those uses. Indeed, suing expressive users should probably disqualify the company from relying on expressive uses to prove fame altogether. ${ }^{54}$ It certainly shouldn't be able to both try to shut down a parody or nominative use and also be able to point to that use as evidence of fame. Requiring that the expressive uses be truly independent may also help avoid a related problem - the assumption that everything requires a license and that the "safe" thing to do is get one even for uses the law expressly permits. ${ }^{55}$

My proposal won't prevent all trademark overreach by any means. Some companies just don't like being made fun of, and they may continue to threaten suit whether the law supports them or not. So it may make sense to combine this proposal with other efforts to punish trademark overreach ${ }^{56}$ to make clearer that these uses are lawful. ${ }^{57}$ But if the goal is to change trademark owner behavior, giving them an affirmative reason to tolerate parodies and other expressive uses - and giving their lawyers a reason to counsel restraint ${ }^{58}$ - is a logical way to get there. ${ }^{59}$

even without dilution traditional trademark owners will seek fame, and we can use that desire to achieve social good.

54. Some rare suits against expressive uses might have merit, and those should not be disqualifying.

55. See Gibson, supra note 15, at 884, 907-08, 912-27 (examining how trademark owners' "rights" snowball when others believe it is "[b]etter [to be] safe than sued"); $c f$. Lawrence Lessig, The Creative Commons, 65 MonT. L. REv. 1, 12 (2004) (describing "the permission culture that our law has produced" in copyright).

56. See supra text accompanying note 36 (citing other scholars who suggest legal sticks, social shame, and other remedies).

57. See Dogan \& Lemley, supra note 4, at 474 (arguing for positive doctrinal reforms to increase clarity and predictability given that current confusion leaves "would-be parodists vulnerable to threats of legal action by trademark holders"); McGeveran, supra note 9, at 49 (making a similar point about the problem of uncertainty and recommending "simpler affirmative defenses that reduce uncertainty and allow for quick adjudication").

58. On the role of lawyers in encouraging or restraining client impulses to attack uses they dislike, see Sheff, supra note 18, at 882.

59. As Glynn Lunney has observed, trademark law often moves in the wrong direction because rules that promote competition generally hurt the self-interest of repeat players in trademark cases, who want to capture rents by excluding competition. See generally Glynn S. Lunney, Jr., Trademark's Judicial De-Evolution: 


\section{CONCLUSION}

Trademark owners often threaten parodists, satirists, and others who make lawful expressive uses of their marks, offering the rationale that they must police their mark against infringement or lose it. But they shouldn't. The law doesn't require policing such uses. Parody, criticism, and being part of the cultural conversation come with the territory of fame. The law should reflect that by treating the existence of those referential uses as indicating that the trademark is strong. By doing so, the law can help align the incentives of trademark owners with good public policy.

Why Courts Get Trademark Cases Wrong Repeatedly, 106 CALIF. L. REV. 1195 (2018). Giving trademark owners an incentive to align their behavior with good social policy might help to break that cycle. 


\section{APPENDIX A}
Fame of Marks Adjudicated Before and After the Trademark Dilution Reform Act of 2006

\section{Famous}

1996

AOL

Arthur the Aardvark

Audi

Barbie

Budweiser

Camel

Candyland

Cartier

Don't Leave Home Without Us

Etch-A-Sketch

Goldfish

Ford

Greatest Show on Earth (circus)

Hotmail

Intermatic

James Bond

Jews for Jesus

Lexington

Nailtiques

NASDAQ

NBA logo

Nike

Panavision

Porsche

Prozac

Sporting News

Toys 'R Us

Tylenol

Velveeta

Victoria's Secret

Wawa

Winston
2006

Adidas three-stripe mark

Audi

America's Team (Dallas Cowboys)

Apple iPhone trade dress

Big Gulp

BlackBerry

Burberry

Chanel

Citibank

Delta

Just Do It

Louis Vuitton Multicolore

McDonald's "Mc" prefix

Miss USA

Motown

Newport

NYC Triathlon

Nike

Pepsi

Rolex

Rolls-Royce

Starbucks

The House that Ruth Built

The Other White Meat

Viagra

Victoria's Secret

Visa 


\section{Not Famous}

1996

Applesee

Authority

Avery Dennison

Bongo

Clue

Columbia

Dearest

Fun Ship

King of the Mountain Sports

Lane Capital Management

Petro

Star Market

Stealth

Children's Place

Teton Glacier

Tornado

Trek

Tycos

We

Weather Guard

Washington Speakers Bureau

We'll Pick You Up

We'll Take Good Care of You
2006

App Store

Bio-Safe

Charlotte

Coach

It's A

Lingo (food market in Del.)

Magenta color (T-Mobile)

Marker's Mark trade dress

Majestic

Movie Mania

Rocky Top

Steak-umm

Top

University of Texas longhorn logo 